\title{
UPAYA DRIVE EKSPOR KOMODITAS BERAS DI INDONESIA
}

Oleh : Anto Ariyanto (antoariyanto@unilak.ac.id)

\section{PENDAHULUAN}

\subsection{Latar Belakang}

Isu ketahanan pangan menjadi topik penting karena pangan merupakan kebutuhan paling hakiki yang menentukan kualitas sumberdaya manusia dan stabilitas sosial politik sebagai prasyarat untuk melaksanakan pembangunan. Karena itu, Pemerintah sangat berkepentingan terhadap masalah pangan, apalagi rata-rata pengeluaran rumah tangga untuk pangan masih di atas 60 persen (Ilham, et al, 2006).

Indonesia pada Tahun 2015 kelak, menghadapi perekonomian terbuka Masyarakat Ekonomi ASEAN yang mana lalulintas barang dan jasa termasuk komoditas pangan terutama beras, menjadi tak kenal batas-batas wilayah. Fenomena produksi, perdagangan, dan konsumsi pangan menuntut campur tangan Pemerintah agar produsen dn konsumen domestik dapat dilindungi. Peran tersebut diharapkan mampu menstabilkan harga pangan, terutama beras, yang dapat dilakukan melalui kebijakan harga pangan agar mengurangi ketidakpastian petani dan menjamin harga menjadi stabil bagi konsumen.

Dengan kondisi demikian, masalah ketahanan pangan akan lebih ditentukan pada aspek daya beli masyarakat dan kontinuitas ketersediaan pangan antarmusim. Tantangan ini menjadi perhatian, dikarenakan Indonesia masih dihadapi pada kondisi spasial dan iklim yang mengakibatkan pasokan pangan, khususnya beras harus senantiasa tersedia secara tepat waktu dan tepat jumlah.

Kemampuan Pemerintah untuk menentukan kebijakan harga yang tepat akan sangat ditentukan bagaimana pemahaman para pengambil kebijakan terhadap struktur, tingkah laku, dan efektivitas pasar. Salahsatu cara memahami struktur, tingkah laku dan efektivitas pasar adalah dengan memahami kekuatan 
relatif suatu pasar serta mekanisme perambatan (transmisi) harga dari satu pasar ke pasar lainnya melalui kajian integrasi pasar.

\subsection{Tujuan Penulisan Makalah}

Penulisan makalah ini mempunyai beberapa tujuan yaitu: mereview kerangka pemikiran tentang upaya drive ekspor beras di Indonesia.

\section{TINJAUAN TEORI}

\subsection{Permintaan dan Penawaran Komoditas Pertanian}

Permintaan dan penawaran komoditas pertanian berkaitan dengan interaksi antara penjual dan pembeli. Interaksi ini akan menentukan tingkat harga yang berlaku dan jumlah komoditas yang diperjualbelikan. Interaksi tersebut dapat diterangkan melalui teori permintaan dan teori penawaran.

\section{a. Teori Permintaan}

Teori permintaan menerangkan sifat dari permintaan pembeli pada suatu komoditas, serta menerangkan hubungan antara jumlah yang diminta, harga, dan pembentukan kurva permintaan (Sugiarto et al. 2007). Suatu komoditas dihasilkan oleh produsen karena dibutuhkan oleh konsumen dan konsumen bersedia membelinya. Konsumen mau membeli komoditas yang mereka perlukan apabila harga produk tersebut sesuai dengan keinginannya. Menurut Rahardja dan Manurung (2008), beberapa faktor yang mempengaruhi permintaan barang yaitu:

1) Harga barang itu sendiri. Sifat hubungan antara permintaan dan harga dijelaskan dalam hukum permintaan. Hipotesis hukum permintaan menyatakan bahwa semakin rendah harga suatu komoditas maka semakin banyak jumlah komoditas tersebut yang diminta, sebaliknya semakin tinggi harga suatu komoditas semakin sedikit komoditas tersebut diminta, ceteris paribus. Menurut Sugiarto et al. (2007), hipotesis tersebut didasarkan atas asumsi: 
a) Bila harga suatu komoditas turun, maka pembelian terhadap komoditas lain yang terkait akan menurun dan menambah pembelian terhadap komoditas yang mengalami penurunan harga tersebut. Penurunan harga suatu komoditas menyebabkan pendapatan riil para pembeli meningkat, sehingga mendorong untuk meningkatkan pembelian.

b) Bila harga suatu komoditas naik, maka pembeli akan mencari komoditas lain yang dapat digunakan sebagai pengganti atas komoditas yang mengalami kenaikan harga. Kenaikan harga menyebabkan pendapatan riil pembeli berkurang, sehingga mendorong pembeli mengurangi pembeliannya.

2) Harga barang lain yang terkait. Keterkaitan dua macam barang dapat bersifat substitusi ataupun komplemen. Menurut Djojodipuro (1991) barang substitusi adalah barang yang memenuhi kebutuhan yang sama. Biasanya barang substitusi tidak mutlak dapat menggantikan satu sama lain, sehingga konsumen dapat memilih mana yang lebih cocok untuk memenuhi kebutuhannya. Pada barang substitusi, bila harga barang yang satu naik, dengan mengabaikan pengaruh pendapatan maka barang yang lain akan naik pula harganya. Hal ini disebabkan kenaikan harga barang yang pertama mengakibatkan pemindahan permintaan ke barang lain dan menaikkan harganya. Oleh karena itu untuk barang substistusi, gerak harganya adalah searah.

3) Tingkat pendapatan perkapita. Tingkat pendapatan perkapita dapat mencerminkan daya beli.

4) Selera atau kebiasaan.

5) Jumlah penduduk.

6) Perkiraan harga dimasa mendatang.

7) Distribusi pendapatan

8) Usaha-usaha produsen meningkatkan penjualan. 


\section{b. Teori Penawaran}

Teori penawaran menerangkan sifat para penjual dalam menawarkan komoditas yang akan dijualnya (Sugiarto et al. 2007). Pernyataan yang menjelaskan sifat hubungan antara harga suatu komoditas dan jumlah komoditas tersebut yang ditawarkan oleh produsen dikenal dengan hukum penawaran. Pada umumnya semakin tinggi harga suatu komoditas, semakin banyak jumlah komoditas tersebut yang akan ditawarkan oleh penjual. Sebaliknya makin rendah harga suatu komoditas makin sedikit jumlah yang ditawarkan oleh penjual. Menurut Rahardja dan Manurung (2008), beberapa faktor yang mempengaruhi penawaran barang yaitu:

1) Harga barang itu sendiri. Sifat hubungan antara harga suatu komoditas dan jumlah penawaran komoditas tersebut dikenal dengan hukum penawaran. Pada umumnya semakin tinggi harga suatu komoditas semakin banyak jumlah komoditas tersebut yang akan ditawarkan oleh penjual.

2) Harga barang lain yang terkait.

3) Harga faktor produksi.

4) Biaya produksi.

5) Teknologi produksi.

6) Jumlah penjual.

7) Tujuan perusahaan.

8) Kebijakan pemerintah.

Menurut Sugiarto et al. (2007) analisis permintaan dan penawaran merupakan alat yang penting untuk:

a. Memahami respon harga dan kuantitas suatu komoditas terhadap perubahan variabel-variabel ekonomi seperti teknologi, selera konsumen, harga komoditas lain, dan harga faktor produksi. 
b. Menganalisis interaksi yang kompetitif antara penjual dan pembeli dalam menghasilkan harga dan kuantitas suatu komoditas.

c. Menunjukkan kebebasan yang diberikan pasar kepada konsumen dan produsen.

d. Menganalisis efek berbagai intervensi kebijakan pemerintah dipasar, seperti pengendalian harga, kuota, pajak, subsidi, dan lain-lain.

\subsubsection{Teori Perdagangan Internasional}

Perdagangan internasional adalah perdagangan yang melintasi antar negara yang mencakup aktivitas ekspor dan impor baik barang maupun jasa (Yuliadi 2007). Teori perdagangan internasional merupakan teori yang mencoba memahami mengapa sebuah negara mau melakukan kerjasama perdagangan dengan negara-negara lain. Berikut ini disampaikan beberapa teori perdagangan internasional.

\section{a. Teori Pra-Klasik Merkantilisme}

Merkantilisme merupakan aliran ekonomi yang tumbuh dan berkembang pesat pada abad XVI sampai dengan XVIII di Eropa Barat. Merkantilisme merupakan ajaran yang berkeyakinan bahwa perekonomian suatu negara makin makmur bila mampu memaksimalkan surplus perdagangan. Konsekuensinya adalah memaksimalkan ekspor sekaligus meminimalkan impor, sehingga surplus perdagangan akan meningkat (Rahardja \& Manurung 2008).Kebijakan ini diadaptasi kembali oleh banyak negara dalam bentuk NeoMerkantilisme. Ciri utamanya yaitu pemeliharaan surplus perdagangan, bila perlumelakukan proteksi. Kebijakan proteksi dilakukan untuk melindungi dan mendorongekonomi industri nasional dengan menggunakan kebijakan tarif dan non tarif. Kebijakan ini dilakukan negara-negara Barat agar negara eksportir memperhatikankelestarian alam dimana setiap produknya mempunyai green label ataupun pemerhatian terhadap hak asasi manusia. Hal ini merupakan salah satu cara yangdilakukan negara kapitalis untuk menghambat ekspor dari negara berkembang. 
Contoh konkret adalah isu perusakan lingkungan yang dilakukan oleh Indonesia yaitu memperluas perkebunan kelapa sawit dengan cara membuka hutan. Isu ini dilontarkan Amerika untuk melindungi perdagangan minyak jagungnya di pasarandunia sehubungan dengan adanya peningkatan ekspor CPO ke beberapa negara. Kebijakan ini juga pernah diterapkan oleh Indonesia dalam bentuk larangan ekspor CPO dan penetapan harga patokan ekspor CPO untuk melindungi industri minyak goreng dalam negeri.

\section{b. Teori Klasik}

\section{1). Teori Absolute Advantage}

Teori keunggulan absolut dikemukakan oleh Adam Smith. Menurutnyaperdagangan akan meningkatkan kemakmuran jika dilaksanakan melalui mekanismeperdagangan bebas Melalui mekanisme perdagangan bebas, para pelaku ekonomidiarahkan untuk melakukan spesialisasi dalam upaya peningkatan efisiensi. Setiapnegara akan memperoleh manfaat perdagangan internasional karena melakukanspesialisasi produksi dan mengekspor barang jika negara tersebut memilikikeunggulan mutlak, serta mengimpor barang jika negara tersebut memiliki ketidak unggulan mutlak (Hady 2001).

\section{2). Teori Comparative Advantage}

Teori keunggulan komparatif dikemukakan oleh David Ricardo yang dikenaldengan model Ricardian. Teori ini didasarkan pada nilai tenaga kerja, yaitu hargasuatu produk ditentukan oleh jumlah waktu atau jam kerja yang diperlukan untuk memproduksinya (Hady 2001). Konsep penting dalam model Ricardian adalahperbedaan sumber daya dan teknologi yang dimiliki oleh tiap negara menciptakankeunggulan bagi negara tersebut (comparative advantage). Ricardo membuktikan bahwa bila dua wilayah yang saling berdagang masing-masing mengkonsentrasikandiri untuk mengekspor barang yang memiliki keunggulan komparatif, maka keduawilayah tersebut akan mendapatkan keuntungan. Atas dasar keunggulan komparatif maka berkembang suatu fenomena yang kemudian disebut spesialisasi yaitu setiapnegara memproduksi sesuatu yang paling 
dikuasainya. Suatu negara dikatakanmempunyai keunggulan komparatif dalam memproduksi suatu komoditi kalau biayapengorbanannya (opportunity cost) dalam memproduksi barang tersebut (dalamsatuan barang lain) lebih rendah daripada negara-negara lainnya (Krugman \&Obstfeld 2000).

\section{c. Teori Modern}

Teori Heckscher-Ohlin menjelaskan bahwa dalam kenyataannya perdagangantidak hanya menunjukkan perbedaan produktivitas tenaga kerja namun jugamencerminkan perbedaan sumber daya di tiap negara yaitu karena adanya perbedaanjumlah atau proporsi faktor produksi yang dimiliki masingmasing negara (Rahardja\& Manurung 2008). Dapat dikatakan bahwa suatu negara sebaiknya mengeksporbarang yang menggunakan faktor produksi yang melimpah dan mengimpor barangyang menggunakan faktor produksi yang langka di negaranya. Namun ekspor danimpor untuk komoditi tersebut hanya dapat dilakukan bila penggunaan faktorproduksi telah dilakukan secara intensif (Krugman \& Obstfeld 2000).

\section{d. International Competitive of Nation Porter's Diamond}

Pada era global yang makin kompetitif diperlukan keunggulan dalam biayaproduksi dan keunggulan kompetitif. Menurut Porter dalam Rahardja dan Manurung(2008), keunggulan kompetitif suatu bangsa bersumber pada beberapa keunggulanberikut:

1) Keunggulan karena faktor produksi (factor conditions)

Faktor produksi yang dimiliki oleh suatu negara yang memberikan kontribusi terhadap keunggulan kompetitif adalah SDM, SDA, iptek, permodalan dan prasarana. 
2) Keunggulan karena faktor permintaan (demand conditions)

Skala dan tingkat pertumbuhan pasar domestik maupun internasional merupakan salah satu faktor penunjang peningkatan daya saing. Skala pasar yang makin membesar dapat menurunkan biaya produksi per unit.

3) Keunggulan karenanjaringan kerja industri (related and supporting industry)

Untuk menjaga dan dan memelihara kelangsungan keunggulan daya saing makaperlu dijaga kontak dan koordinasi dengan supplier.

4) Keunggulan karena strategi perusahaan dan struktur persaingan pasar (firmstrategy, structure and rivalry)

Strategi perusahaan, struktur organisasi dan kondisi persaingan antara perusahaandomestik yang sangat ketat dan tidak adanya proteksi pemerintah akan memaksaperusahaan memperbaiki kondisi internalnya. Hal ini mampu mendorongperusahaan bekerja efisien dan produktif sehingga dapat bersaing di pasar global.

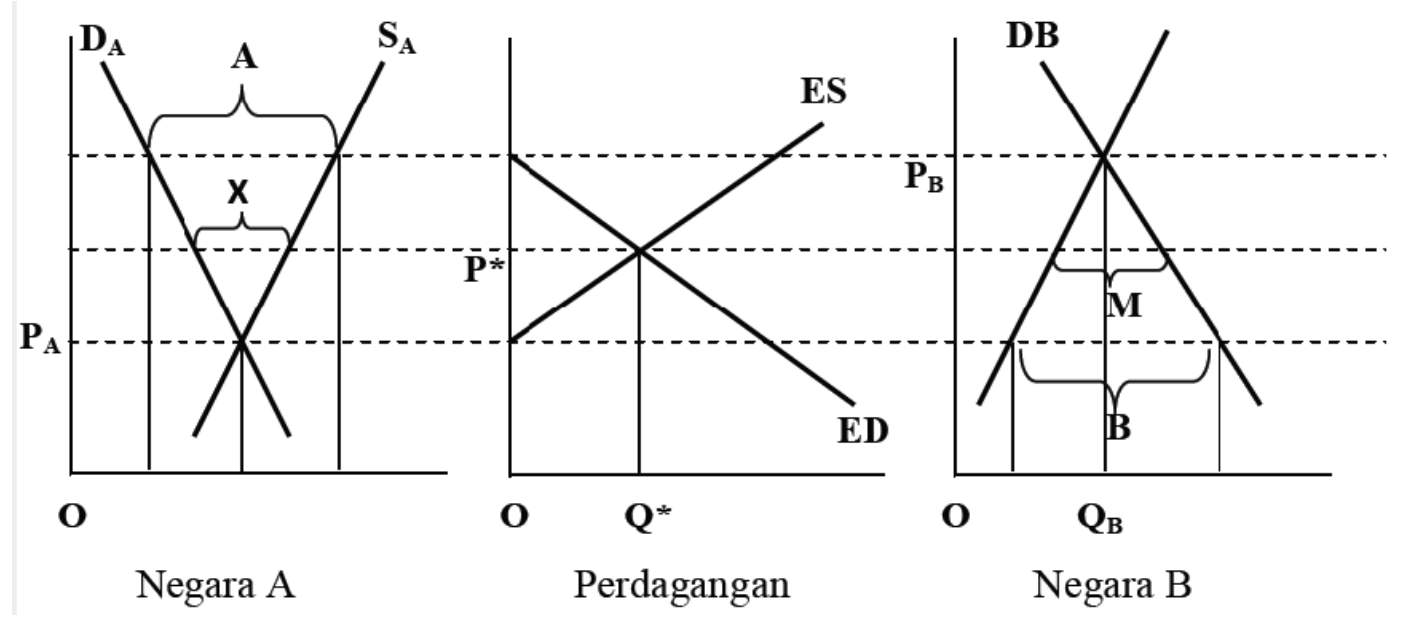

Gambar 1. Kurva Perdagangan Internasional Antar Dua Negara Sumber: Salvatore (1997) 
Teori perdagangan internasional menunjukkan bahwa tiap negara memiliki perbedaan sumber daya dalam memproduksi suatu barang sehingga menciptakan keunggulan untuk komoditi yang sama. Perbedaan harga menjadi dasar terjadinya arus perdagangan antar negara yang secara grafis dijelaskan Gambar 1.

Gambar 1. memperlihatkan sebelum terjadinya perdagangan internasional harga di negara $\mathrm{A}$ sebesar $\mathrm{P}_{\mathrm{A}}$, sedangkan di negara $\mathrm{B}$ sebesar $\mathrm{P}_{\mathrm{B}}$. Penawaran pasar internasional akan terjadi jika harga internasional lebih tinggi dari $\mathrm{P}_{\mathrm{A}}$ sedangkan permintaan di pasar internasional akan terjadi jika harga internasional lebih rendah dari $\mathrm{P}_{\mathrm{B}}$. Pada saat harga internasional $\left(\mathrm{P}^{*}\right)$ sama dengan $\mathrm{P}_{\mathrm{A}}$ maka negara $\mathrm{B}$ akan terjadi excess demand (ED) sebesar B. Jika harga internasional sama dengan $\mathrm{P}_{\mathrm{B}}$ maka di negara A akan terjadi excess supply (ES) sebesar A. Dari A dan B akan terbentuk kurva ES dan ED yang akan menentukan harga yang terjadi di pasar internasional sebesar $\mathrm{P}^{*}$. Dengan adanya perdagangan tersebut, maka negara A akan mengekspor komoditas (pakaian jadi) sebesar X sedangkan negara B akan mengimpor komoditas (pakaian jadi) sebesar $\mathrm{M}$, dimana di pasar internasional sebesar X sama dengan M yaitu $\mathrm{Q}^{*}$.

Faktor-faktor yang mempengaruhi ekspor menurut Darmansyah dalamSoekartawi (1991) seperti diuraikan berikut ini :

a. Harga Internasional

Makin besar selisih antar harga di pasar internasional dengan harga domestikakan menyebabkan jumlah komoditi yang akan diekspor menjadi bertambahbanyak. Naik turunnya harga tersebut disebabkan oleh:

1). Keadaan perekonomian negara pengekspor, dimana dengan tingginya inflasidi pasar domestik akan menyebabkan harga dipasar domestik menjadi naik. Jika ditinjau dari pasar internasional secara riil harga komoditi tersebut akan terlihat semakin menurun.

2). Harga di pasar internasional semakin meningkat, dimana harga internasional merupakan keseimbangan antara penawaran ekspor dan 
permintaan impor suatu komoditas di pasar dunia meningkat. Jika harga komoditas di pasar domestik tersebut stabil, maka selisih harga internasional dan harga domestik semakin besar, akibatnya akan mendorong ekspor komoditi tersebut.

b. Nilai tukar uang

c. Kuota ekspor impor

d. Kebijakan tarif dan non tarif

Kebijakan tarif dan non tarif dimaksudkan untuk menjaga harga produk dalam negeri dalam tingkatan tertentu sehingga dengan harga tersebut dapat atau mampu mendorong pengembangan komoditi tersebut.

\section{PEMBAHASAN}

\subsection{Permintaan dan Penawaran Beras di Indonesia}

Kondisi permintaan dan penawaran beras di Indonesia dapat diidentifikasi berdasarkan perkembangan yang berkaitan dengan produksi, konsumsi, dan stok beras. Perkembangan dari hal-hal tersebut akan diuraikan sebagai berikut.

\subsubsection{Produksi}

Salah satu upaya yang dilakukan untuk mewujudkan swasembada beras secara nasional pada tahun 2008, yaitu dengan peningkatan produksi beras. Besarnya produksi beras diperoleh dari hasil perkalian antara produksi padi dengan faktor konversi atau tingkat rendemen pengolahan padi menjadi beras seperti yang telah ditetapkan oleh pemerintah, yaitu sebesar 0.63. Sementara, besarnya produksi padi ditentukan oleh luas areal panen dan tingkat produktivitas padi (Nainggolan dan Suprapto, 1987). Luas areal panen, produktivitas, dan produksi padi di Indonesia disajikan pada Tabel 1. 
Tabel 1. Luas Areal Panen, Produktivitas, dan Produksi Padi di IndonesiaTahun 2004-2008

\begin{tabular}{|c|c|c|c|c|}
\hline No. & Tahun & Luas Areal Panen (Ha) & Produktivitas (ton/Ha) & Produksi (ton) \\
\hline 1. & 2004 & $11,922.97$ & 4.54 & $54,088.47$ \\
\hline 2. & 2005 & $11,839.06$ & 4.57 & $54,151.10$ \\
\hline 3. & 2006 & $11,786.43$ & 4.62 & $54,454.95$ \\
\hline 4. & 2007 & $12,147.64$ & 4.71 & $57,157.44$ \\
\hline 5. & 2008 & $12,327.43$ & 4.89 & $60,325.93$ \\
\hline
\end{tabular}

Sumber: BPS, 2009

Berdasarkan Tabel 1. dapat dilihat bahwa produksi padi tahun 2006 sebesar 54.45 juta ton Gabah Kering Giling (GKG) bertambah sebesar 303.85 ribu ton dibanding dengan produksi tahun 2005. Kenaikan produksi tahun 2006 diimbangi dengan peningkatan produktivitas sebesar 0.05 ton/hektar namun luas panen mengalami penurunan seluas 52.63 ribu hektar. Peningkatan produksi padi tersebut dapat disebabkan oleh adanya usaha-usaha intensifikasi pertanian seperti pemakaian air irigasi yang efektif dan efisien, penggunaan bibit unggul, dan pemakaian pupuk yang tepat guna dan tepat sasaran (Girsang, 2009).

Ketersediaan lahan persawahan memiliki peran yang sangat penting terhadap dinamika produksi padi. Peningkatan luas panen padi dapat ditempuh melalui pembangunan jaringan irigasi yang memungkinkan peningkatan intensitas tanam padi per tahun dan peningkatan luas sawah melalui pencetakan sawah baru. Namun demikian, keterbatasan sumberdaya lahan dan anggaran pembangunan menyebabkan kedua upaya tersebut semakin sulit diwujudkan (Irawan, 2005).

\subsubsection{Konsumsi}

Saat ini beras mendominasi pola konsumsi pangan penduduk Indonesia. Beras menjadi bahan makanan yang lebih superior daripada bahan makanan lainnya seperti jagung, ketela, ikan, dan lainnya. Data konsumsi rata-rata per kapita seminggu beberapa macam bahan makanan penting Indonesia disajikan pada Tabel 2. 
Tabel 2. Konsumsi Rata-rata Per Kapita Seminggu Beberapa Macam Bahan Makanan Penting Indonesia (rupiah) Tahun 2005, 2007, 2008

\begin{tabular}{|c|l|c|c|c|c|}
\hline No. Jenis Makanan & Satuan & $\mathbf{2 0 0 5}$ & $\mathbf{2 0 0 7}$ & $\mathbf{2 0 0 8}$ \\
\hline 1. & Beras & $\mathrm{Kg}$ & 1.872 & 1.740 & 1.797 \\
\hline 2. & Jagung basah berkulit & $\mathrm{Kg}$ & 0.018 & 0.046 & 0.024 \\
\hline 3. & Jagung pocelan, pipilan & $\mathrm{Kg}$ & 0.047 & 0.060 & 0.044 \\
\hline 4. & Ketela pohon & $\mathrm{Kg}$ & 0.161 & 0.134 & 0.147 \\
\hline 5. & Ketela rambat & $\mathrm{Kg}$ & 0.060 & 0.046 & 0.051 \\
\hline 6. & Gaplek & $\mathrm{Kg}$ & 0.003 & 0.005 & 0.005 \\
\hline 7. & Ikan dan udang segar & $\mathrm{Kg}$ & 0.281 & 0.260 & 0.263 \\
\hline 8. & Ikan dan udang diawetkan & ons & 0.499 & 0.523 & 0.537 \\
\hline 9. & Daging sapi, kerbau & $\mathrm{Kg}$ & 0.010 & 0.008 & 0.007 \\
\hline 10. & Daging ayam ras, kampung & $\mathrm{Kg}$ & 0.076 & 0.079 & 0.073 \\
\hline 11. & Telur ayam & $\mathrm{Kg}$ & 0.106 & 0.122 & 0.115 \\
\hline 12. & Telur itik, manila, asin & butir & 0.075 & 0.093 & 0.088 \\
\hline 13. & Susu kental manis & 397 gr & 0.057 & 0.068 & 0.061 \\
\hline 14. & Susu bubuk kaleng, bayi & $\mathrm{Kg}$ & 0.018 & 0.026 & 0.025 \\
\hline 15. & Tahu & $\mathrm{Kg}$ & 0.153 & 0.163 & 0.137 \\
\hline 16. & Tempe & $\mathrm{Kg}$ & 0.159 & 0.152 & 0.139 \\
\hline 17. & Minyak kelapa, goreng & liter & 0.195 & 0.198 & 0.196 \\
\hline 18. & Kelapa & butir & 0.209 & 0.216 & 0.184 \\
\hline 19. & Gula pasir & ons & 1.618 & 1.654 & 1.617 \\
\hline 20. & Gula merah & ons & 0.192 & 0.209 & 0.188 \\
\hline
\end{tabular}

Catatan:

1) Ikan segar meliputi ikan darat, laut, dan udang

2) Satu butir telur ayam diperkirakan beratnya sebesar $0.05 \mathrm{Kg}$ (Sumber: BPS, 2009)

\subsubsection{Stok, Pengadaan, dan Penyaluran Beras}

Campur tangan pemerintah dalam ekonomi perberasan antara lain dilakukan melalui lembaga pangan yang bertugas melaksanakan kebijakan pemerintah di bidang perberasan baik yang menyangkut aspek pra produksi, proses produksi, dan pasca produksi. Salah satu lembaga pangan yang mendapat tugas dari pemerintah untuk menangani masalah pascaproduksi beras khususnya dalam bidang harga, pemasaran, dan distribusi adalah Badan Urusan Logistik (Bulog) (Saifullah, 2001).

Sesuai dengan perkembangan kondisi perberasan di Indonesia, tugas pokok Bulog dibatasi hanya pada komoditi beras. Hal ini telah termaktub dalam Keputusan Presiden (Keppres) No. 29 Tahun 2000. Sejak 1 Januari 2003, dengan mengacu pada Keppres No. 103 Tahun 2001 yang kemudian direvisi lagi dengan Keppres No. 110 Tahun 2001 serta Keppres No. 3 Tahun 2002, Bulog yang pada awalnya berbentuk Lembaga Pemerintah Non Departemen (LPND) berubah menjadi Badan Usaha Milik Negara (BUMN) berbentuk Perusahaan Umum 
(Perum). Dengan berbentuk Perum, tugas Bulog sama dengan BUMN lainnya, yaitu berusaha mencari keuntungan dalam segala kegiatannya. Meskipun demikian Bulog diharapkan tetap menjalankan misi sosialnya sebagai Public Service Obligation (PSO) dalam menyalurkan beras untuk keluarga miskin (Raskin) dan menjaga stabilisasi harga beras petani.

Tugas Bulog tersebut berdasarkan pada Peraturan Menteri Perdagangan RI (Permendag) No. 22/M-DAG/PER/10/2005 tentang penggunaan cadangan beras pemerintah (CBP) untuk pengendalian gejolak harga. Pertama, CBP adalah sejumlah tertentu beras milik pemerintah pusat yang pengadaannya didanai oleh Anggaran Pendapatan dan Belanja Negara (APBN) sebagai cadangan stok beras nasional dan dikelola oleh Perum Bulog dengan arah penggunaan untuk penanggulangan keadaan darurat, kerawanan pangan pasca bencana, pengendalian gejolak harga beras, dan untuk memenuhi kesepakatan Cadangan Beras Darurat ASEAN (ASEAN Emergency Rice Reserve). Kedua, gejolak harga beras adalah kenaikan harga beras di tingkat konsumen mencapai lebih dari 25 persen dari harga normal dan berlangsung selama seminggu. Ketiga, harga normal adalah harga rata-rata beras kualitas medium di tingkat konsumen yang telah berlangsung selama tiga bulan sebelum terjadinya gejolak harga beras. Keempat, beras kualitas medium adalah beras dengan kualitas yang setara dengan CBP.

Pengadaan beras nasional yang dibeli oleh pemerintah dari petani disimpan dan disalurkan pada gudang-gudang Bulog. Pemerintah mewajibkan Bulog untuk menjaga stok yang aman sepanjang tahun sebesar satu sampai satu setengah juta ton beras. Jika jumlah ini berkurang, maka kewajiban Bulog untuk segera mengisinya kembali baik melalui pengadaan beras dalam negeri maupun melalui impor. Untuk mengetahui perkembangan pengadaan dan penyaluran beras oleh Bulog dapat dilihat pada Tabel 3. 
Tabel 3. Pengadaan dan Penyaluran Beras (juta ton) di Indonesia Tahun 2005-2008

\begin{tabular}{|c|l|c|c|c|c|}
\hline No. & \multicolumn{1}{|c|}{ Deskripsi } & $\mathbf{2 0 0 5}$ & $\mathbf{2 0 0 6}$ & $\mathbf{2 0 0 7}$ & $\mathbf{2 0 0 8}$ \\
\hline 1. & Pengadaan Beras & 1.53 & 1.43 & 1.77 & 3.20 \\
\hline 2. & Penyaluran Beras & 2.23 & 1.62 & 1.52 & 2.67 \\
\hline
\end{tabular}

Sumber: Bulog, 2008

Tabel 3. menunjukkan bahwa jumlah pengadaan dan penyaluran beras cenderung berfluktuasi. Jumlah pengadaan dan penyaluran beras tertinggi dari data tahun 2005 sampai 2008 adalah pada tahun 2008 sebesar 3.20 dan 2.67 juta ton. Jumlah pengadaan beras terendah pada tahun 2006 sedangkan jumlah penyaluran beras terendah pada tahun 2007 .

\subsubsection{Kebijakan Pemerintah dalam Perberasan}

Kebijakan adalah suatu peraturan yang telah dirumuskan dan disetujui untuk dilaksanakan guna mempengaruhi suatu keadaan (Firdaus et al., 2008). Kebijakan berguna sebagai alat pemerintah untuk campur tangan dalam mempengaruhi perubahan secara sektoral dalam masyarakat. Begitu pula, termasuk di dalamnya kebijakan pada sektor pertanian. Berdasarkan Instruksi Presiden (Inpres) No. 2 Tahun 2005 kebijakan perberasan di Indonesia terbagi menjadi kebijakan harga, kebijakan produksi, kebijakan distribusi, dan kebijakan impor.

Kebijakan pemerintah yang paling menonjol pada pemasaran beras di Indonesia yang dimulai sejak tahun 1968-1969 adalah kebijakan harga, stabilitas harga dalam negeri, dan perdagangan (Darwanto, 2005). Sebagai instrumen kebijakan harga adalah penetapan harga dasar dengan tujuan meningkatkan produksi beras dan pendapatan petani melalui pemberian jaminan harga yang wajar dan penetapan batasan harga eceran tertinggi dengan tujuan memberikan perlindungan kepada konsumen. Agar pelaksanaan kebijakan berjalan efektif, pemerintah menunjang dengan sistem pengelolaan stok beras nasional melalui Perum Bulog di tingkat nasional dan Depot Logistik (Dolog) untuk tingkat propinsi. 
Melalui Inpres No. 9 Tahun 2002, pemerintah mengubah istilah Harga Dasar Gabah (HDG) menjadi Harga Dasar Gabah Pembelian Pemerintah (HDPP) atau lebih dikenal dengan Harga Pembelian Pemerintah (HPP). Kebijakan HPP hanya menjamin harga gabah pada tingkat tertentu di lokasi yang telah ditetapkan,tetapi tidak lagi menjamin HDG minimum di tingkat petani. HPP juga berlaku di gudang Bulog, bukan di tingkat petani sebagaimana kebijakan HDG.

Apabila perubahan secara drastis mungkin akan membuat gejolak, maka diperlukan kebijakan transisi dalam bentuk kebijakan HPP. Melalui kebijakan ini pemerintah melakukan pembelian (pada waktu panen raya) dengan jumlah yang ditentukan pada tingkat harga pasar. Kebijakan ini akan menambah permintaan sehingga pada tingkat harga pasar, petani telah memperoleh keuntungan yang memadai. Selain kebijakan diatas, beberapa kebijakan beras nasional lainnya adalah kebijakan produksi yang bertujuan untuk mencukupi kebutuhan beras domestik melalui intensifikasi dan ekstensifikasi, kebijakan impor yang bertujuan untuk menekan dan mengurangi tingkat ketergantungan impor beras Indonesia yang diimplementasikan melalui dua instrumen pokok, yaitu hambatan tarif dan non tarif (kuota tarif), dan kebijakan distribusi yang diperlukan untuk menjaga ketahanan pangan setiap daerah.

Pada tahun 2000 pemerintah mengeluarkan kebijakan protektif dengan menetapkan tarif impor spesifik sebesar Rp 430 per kilogram. Kemudian nilai tarif tersebut dikoreksi kembali pada akhir tahun 2004 menjadi sebesar Rp 450 per kilogram yang bertujuan untuk menekan laju impor beras dari pasar dunia serta untuk pengamanan HPP.

Pemerintah Indonesia sejak tahun 2003 menempuh kebijakan non tarif yang bersifat protektif, disamping kebijakan tarif yang sudah ada, yaitu berupa ketentuan tentang importansi beras tertuang dalam Surat Keputusan Menteri Perindustrian dan Perdagangan No. 9/MPP/Kep/1/2004 tentang Ketentuan Impor Beras. Beberapa ketentuan penting adalah: (1) impor beras hanya dapat dilakukan oleh importir yang telah mendapat pengakuan sebagai Importir Produsen Beras (IP Beras) dan importir yang telah mendapat penunjukan sebagai Importir 
Terdaftar Beras (IT Beras), (2) impor beras dilarang dalam masa satu bulan sebelum panen raya, selama panen raya, dan dua bulan setelah panen raya (ditetapkan oleh Menteri Pertanian), yang berarti impor beras hanya boleh dilakukan diluar masa-masa yang telah ditetapkan tersebut, (3) pelaksanaan importasi beras oleh IT Beras hanya dapat dibongkar di pelabuhan tujuan sesuai dengan persetujuan impor yang diberikan oleh Direktorat Jenderal Perdagangan Luar Negeri, dan (4) beras yang diimpor oleh IP Beras hanya boleh digunakan sebagai bahan baku untuk proses produksi industri yang dimilikinya dan dilarang diperjualbelikan atau dipindahtangankan. Kombinasi kedua kebijakan defensif tersebut diharapkan dapat meredam laju impor dan mampu mengangkat harga beras di pasar domestik dan harga gabah petani (Hadi dan Wiryono, 2005).

\subsubsection{Kebijakan Ekspor Beras}

Pada tahun 2009, pemerintah Indonesia pernah berkeinginan untuk mengekspor beras. Produksi beras pada saat itu naik cukup tinggi dalam 2 tahun terakhir, juga pada 2009. BPS waktu itu meramalkan bahwa produksi beras hampir 39,5 juta ton pada 2009. Produksi naik masing-masing 4,96 persen (2007), 5,55 persen (2008), dan 3,71 persen (2009).

Pada tahun 2008, pemerintah telah mendeklarasikan bahwa Indonesia telah mampu merebut kembali swasembada beras, mengulang apa yang pernah dicapai pada pertengahan 1980-an. Pada 2009, Indonesia diperkirakan akan kelebihan produksi beras DN, sehingga sebagian surplus produksi tersebut dianggap layak untuk diekspor. Surplus produksi beraslah yang sering dipakai sebagai alasan perlunya ekspor.

Berbagai pertemuan lintas departemen/lembaga telah dilakukan, sejumlah

surat keputusan (SK) Mendag telah dikeluarkan. Dalam Permendag no.12/MDAG/PER/4/2008 (April 2008) dijelaskan bahwa hanya Perum Bulog yang diizinkan ekspor beras kualitas patahan kurang dari 5 persen, atau kualitas 5 25 persen, dan Bulog ditunjuk sebagai eksportir tunggal. Hal itu memang layak 
karena Bulog adalah STE (State Trading Enterprise) yang telah terdaftar di WTO, disamping itu pemerintah akan lebih efektif dalam mengelola ekspor yang dilakukan Bulog dibandingkan swasta. Sama seperti impor beras, pemerintah ternyata lebih efektif dalam mengelola impor beras, manakala hal itu dikelola oleh Bulog sejak 2007.

Dalam perjalanannya, ternyata ketentuan itu belum bulat diterima oleh departemen lain, terutama Deptan. Deptan berpendapat bahwa program beras sertifikat organik atau jaminan mutu, tersedianya beras unggul lokal seperti Kaltim, atau beras unggul lain, seperti beras merah dan beras hitam, yang telah punya pasar ekspor atau berpeluang untuk diekspor. Dalam kerangka itulah maka swasta perlu dilibatkan untuk mengeskpor beras, khususnya untuk jenis seperti yang telah disebutkan di atas. Tampaknya, argumentasi tersebut belum dikuatkan oleh data kuantitatif tentang volume dan penyebarannya, serta negara tujuan ekspor. Apakah benar pasar untuk jenis beras tersebut telah tersedia dan berapa kira-kira pangsa pasarnya? Belum lagi, pertanyaan sekitar sertifikasi beras organik, apakah itu mengacu ke standar internasional, atau ke standar Negara tertentu. Jepang misalnya, menerapkan sertifikasi beras organik yang berbeda kriterianya dengan EU. Tanpa memahami hal itu, diperkirakan Indonesia akan kesulitan dalam menembus pasar ekspor, terutama beras khusus, seperti yang telah disebutkan di atas.

Para petani kita sering mengklaim bahwa mereka telah memproduksi beras organik, karena mereka tidak menggunakan pupuk kimia atau pestisida. Itu ternyata tidak cukup, mengingat air irigasi mengalir dari satu petak sawah ke petak sawah lainnya, yang mungkin sebagian mereka masih menggunakan pupuk kimia dan lain-lain. Demikian juga, petak sawah yang bertingkat, sehingga petani yang berada di atasnya menggunakan pupuk kimia, akan berdampak pada petak sawah di bawahnya yang melaksanakan padi organik.

Akhirnya Permendag itu direvisi, dan dikeluarkanlah belit baru seperti yang tertuang dalam Permendag no.13/M-DAG/PER/3/2009 pada Maret 2009. BUMN dan BUMD, serta swasta diizinkan untuk ekspor beras dengan kualitas 
patahan (broken) kurang 5 persen. Bulog hanya diizinkan ekspor beras pada kualitas patahan 5-25 persen. Atas dasar itulah, maka pemerintah mengizinkan 8 perusahaan swasta untuk melaksanakannya, disamping tentunya Bulog. Demikian juga, ekspor diizinkan hanya pada kualitas super dan aromatik serta beras khusus (organik). Namun sayangnya maksud untuk ekspor beras Indonesia belum sepenuhnya terwujud.

Priyono (2009b) menilai minimnya realisasi ekspor beras disebabkan oleh 3 masalah utama yaitu kualitas, prosedur dan waktu ekspor. Tampaknya Indonesia mampu memenuhi syarat butir patahan (broken) dan derajat sosoh (milling degree) yaitu setelah dilakukan grading dan polishing beras asalan, namun sulit memenuhi kemurnian varietas. Beras dominan yang diekspor tersebut adalah veritas short grain, jenis Muncul. Namun jenis beras tersebut tercampur dengan beras kualitas lain (IR dan Ciherang), yang melebihi ketentuan kesepakatan (26\%). Walaupun dilakukan sortasi dengan alat yang ada yaitu length grader ternyata tidak efektif. Disamping itu, alat proses yang sama dipakai untuk varietas lain, tanpa dibersihkan, sehingga sisa dalam peralatan, terutama pada Silo/Bin dan Conveyor/Elevator). Prosedur juga kurang dipatuhi oleh surveyor walau mereka berafiliasi dengan surveyor tingkat internasional, sehingga harus dibongkar ulang, karena belum selesai analisa kualitas beras yang diekspor.

Para eksportir juga belum berdisiplin dalam melakukan persyaratan ekspor, karena persyaratan amat ketat, tidak sebanding dengan ketentuan PIBC (Pasar Induk Beras Cipinang) Jakarta. Waktu yang tersedia untuk ekspor amat terbatas, hanya 2 bulan sejak izin ekspor sampai batas akhir izin ekspor sampai dengan 30 Juni 2009. Itu waktu amat singkat, karena mereka memakai kapal feeder pengangkut kontainer yang sulit dikontrol waktunya, disamping singkatnya waktu pengapalan. 


\subsubsection{Kontroversi Antara Kebijakan Ekspor Beras dengan Ketahanan Pangan}

Kondisi Ketahanan Pangan di Indonesia Ketahanan pangan mencakup ketersediaan bahan pangan untuk tingkat individu, rumah tangga, dan nasional. Ketahanan pangan dalam suatu Negara dapat dikatakan baik apabila masyarakat dapat memperoleh komoditas pangan dengan mudah dan dengan harga yang murah. Sementara itu, kenyataan yang terjadi di Indonesia dirasakan masih kurang dikarenakan kurangnya perhatian masyarakat dan pemerintah terhadap aspek pertanian itu sendiri. Cara pandang masyarakat Indonesia terhadap sektor pertanian berpengaruh terhadap perkembangan sektor pertanian di Indonesia

Dengan adanya surplus beras, Pemerintah mencanangkan kebijakan ekspor beras. Kebijakan ekspor beras merupakan kebijakan yang dilakukan oleh Pemerintah Indonesia untuk mengirim sejumlah pasokan beras yang berlebih ke berbagai negara tujuan ekspor.

Dengan adanya kebijakan ekspor beras, berarti surplus yang terjadi di Indonesia akan dijual ke Negara lain. Kebijakan ini dilakukan oleh pihak pemerintah, yaitu Bulog. Keuntungan yang diperoleh dari kebijakan ekspor beras ini adalah berupa peningkatan devisa Negara yang bersifat sementara karena pendapatan yang diperoleh dari ekspor tersebut, sewaktu-waktu bisa saja digunakan untuk membiayai impor pada masa yang akan datang. Sementara itu di lain pihak, Pemerintah, terutama Bulog akan lebih diuntungkan dengan adanya kebijakan ekspor beras tanpa memikirkan dampak lain yang akan terjadi.

Melihat kenyataan yang ada di Indonesia mengenai ketahanan pangan, kebijakan ekspor beras dirasakan terlalu menimbulkan polemik karena ketahanan pangan di Indonesia bahkan belum memenuhi standard yang baik. Stok ketersediaan beras di Indonesia hanya berlebih sedikit, bukan surplus besarbesaran, namun dengan kondisi yang seperti itu saja, Pemerintah berani mengambil langkah berupa kebijakan ekspor beras. Padahal seluruh rakyat Indonesia belum memperoleh aksessibilitas yang merata untuk komoditas pangan, apalagi harga komditas pangan yang selalu berfluktuasi bahkan cenderung selalu meningkat diakibatkan meningkatnya permintaan masyarakat. Oleh sebab itu, 
tidak ada kesempatan bagi rakyat miskin untuk memperoleh beras dengan harga yang murah dan tentunya dengan kualitas tinggi.

Namun di samping itu, pemerintah Bulog memberi keringanan dengan menjual beras RASKIN, yang diperuntukkan bagi kalangan bawah dengan harga yang murah. Namun hal ini cukup menimbulkan pertentangan dikarenakan beras yang disediakan pemerintah untuk rakyat miskin adalah beras dengan kualitas yang rendah. Disamping karena jumlah produksi beras tersebut belum stabil di setiap masa panen, aksessibilitas masyarakat dalam memperolah beras itu sendiri pun masih kurang merata.

Dengan demikian, untuk mecapai ketahanan pangan yang berkelanjutan, diperlukan perbaikan di sektor pertanian yakni perbaikan sistem irigasi, subsidi pupuk, dan penggunaan bibit unggul. Selain itu, lahan pertanian yang dimanfaatkan seoptimal mungkin dengan tidak mengeksploitasi lahan pertanian agar tidak dialihfungsikan menjadi lahan untuk sektor industri yang pada akhirnya dapat merugikan lingkungan sebagai akibat dari limbah-limbah yang mereka hasilkan.

\section{KESIMPULAN}

\subsection{Kesimpulan}

Indonesia seperti Negara Berkembang lain, hampir tidak pernah menempuh kebijakan subsidi ekspor untuk produk pertanian, walau Indonesia negara eksportir penting untuk sejumlah komoditas pertanian, seperti CPO, karet, kopi, kakao. Kebijakan yang umum ditempuh adalah memajaki ekspor dengan alasan untuk memupuk penerimaan pemerintah, tidak peduli dengan perluasan pasar. Padahal, hasil pajak ekspor tersebut tidak jelas pemanfaatannya untuk membantu petani produsen. Misalnya, pada saat mereka menghadapi kesulitan akibat merosotnya harga CPO, pemerintah diam. Malah hasil pajak ekspor itu digunakan untuk membiayai subsidi migor, untuk kepentingan konsumen, bukan 
buat "memperkuat" produsen. Namun, sebaliknya yang terjadi di Negara Maju, mereka menempuh kebijakan subsidi eskpor, untuk ekspansi perdagangan, termasuk juga memperkuat peran Multi National Corporations (MNCs) di pasar global.

Ekspor beras kualitas medium (setara beras Bulog) hanya mampu dilakukan apabila pemerintah bersedia mensubsidi ekspor sebesar USD 200/ton. Kalau ekspor mencapai 100 ribu ton misalnya, maka total subsidi ekspor beras menjadi sekitar USD 20 juta atau sekitar Rp 200 milyar. Pemerintah dan DPR diperkirakan akan sulit menerima subsidi ekspor, terutama beras. Kalau ingin Kebijakan ekspor beras yang dicanangkan oleh pemerintah untuk saat ini belum tepat karena masih terdapat ketidaksiapan, seperti masih terjadi kurangnya aksessibilitas masyarakat untuk memperoleh beras. Selain itu, cadangan beras yang ada di Bulog saat ini belum dapat dikatakan mencukupi ekspor beras karena diperkirakan cadangan beras yang berlebiih tersebut hanya berlaku sampai pada bulan Mei 2009. Sehingga, alangkah lebih baik jika pemerintah memperbaiki distribusi beras domestik terlebih dahulu agar kelak dapat tercapai katahanan pangan yang berkelanjutan.

\subsection{Saran}

Untuk saat ini, lebih baik pemerintah lebih memfokuskan pemerataan distribusi pangan domestik daripada mengekspor seluruh cadangan beras yang dimiliki karena hal tersebut memiliki beberapa dampak positif, antara lain :

1. Dengan adanya cadangan beras yang berlebih, pemerintah tidak perlu melakukan impor beras lagi, meskipun pada awalnya Indonesia ddiperkirakan harus mengimpor beras hingga satu juta ton. Dengan demikian, pemerintah dapat menghemat devisa Negara dalam jumlah yang cukup besar.

2. Dengan adanya penghemetan devisa tersebut, akan terjadi peningkatan penyerapan gabah petani, dan ini akan berdampak pada pertumbuhan ekonomi pedesaan. 
3. Indonesia mampu menjaga stabilitas harga nasional di tengah gejolak harga pangan dunia. Saat harga pangan dunia meroket, harga beras dalam negeri tak terpengaruh. Begitupun saat harga pangan turun, stabilitas harga beras dalam negeri tetap terisolasi dari pengaruh dunia tersebut.

Dengan berbagai implikasi yang ada tersebut, pada akhirnya, stok cadangan beras yang kita miliki juga mampu meningkatkan kesejahteraan petani, serta memantapkan kemandirian pangan (swasembada) dalam memelihara stabilitas sosial, ekonomi dan politik.

\section{DAFTAR PUSTAKA}

Dong K. Son dan Trans C. Thang. 2008. "Role of State-Owned Enterprises in Vietnam's Rice Market”, in Rashid, Gulati and Cummings Jr (Eds), From Parastatal to Private Trade: Lessons from Asian Agriculture, The Johns Hopkins Univ.Press: Baltimore

FAO. 2006. "Import Surges: What are their external causes?", FAO Briefs on Import Surges: Issues no. 3

Priyono, H. 2009a. "Pasar Beras: Kualitas, Harga dan Preferensi Konsumen", Warta Intra Bulog, Edisi 01/35/2009

Priyono, H. 2009b. “Ekspor Beras: Sebuah Anti Klimaks?”, Warta Intra Bulog, Edisi 05/36/2009.

Sawit, M.H. 2005. Perum Bulog dalam Perjanjian Pertanian WTO: Apa, Mengapa dan Bagaimana, Puslitbang Bulog: Jakarta

Sawit, M.H. 2007. Liberalisasi Pangan: Ambisi dan Reaksi dalam Putaran Doha WTO, Badan Penerbit FE UI: Jakarta 